\title{
Proceeding
}

Supplementary Issue: Spring Conferences of Sports Science. Costa Blanca Sports Science Events, 14-15 June 2019. Alicante, Spain.

\section{Longitudinal case study of the role of libero in volleyball}

\author{
FRANCESCA MARRA ${ }^{1}$, MATTEO AQUINO ${ }^{1}$, GAETANO ALTAVILLA $^{2}$ \\ 1 University of Salerno, Italy \\ 2University of Split, Croatia
}

\begin{abstract}
In volleyball, the role of libero is highly specialized compared to the others, thanks to high abilities in the individual fundamental of the Bagher and in the team fundamentals of reception and defence. Therefore, coaches are committed to differentiate training programs from those of the remaining team members and this also affects the checks: in fact, results will have a greater weight compared to the same efficacy measurements of the fundamental of the Bagher of other roles. It's therefore very useful to monitor, through a series of tests, the work done in the gym: results will help to recalibrate the training plan to combine team goals with needs of the libero. The purpose of this study is to monitor the level of efficacy of the individual fundamental of the Bagher, employed in the following moments of game: free-ball; service receiving; spike defence. To do this, the tests were: Bagher of free-ball in zone 5; receiving Bagher in zone 1 and in zone 6; defence Bagher in zone 5. The method is experimental longitudinal and consists in detecting the initial and final data in a period of time of 8 months for the technical ability in the aforementioned fundamental of a player in the role of libero in series B1. From the results, it comes out that the training activities are constantly monitored and the purpose can be considered achieved, because the coach has verified the athlete's performance level over time noting a final performance improvement, also confirmed by the game-data. Keywords: Enable capacity; High level women's volleyball; Tests; Longitudinal case; Role of libero; Monitoring and evaluation system.

\section{Cite this article as:}

Marra, F., Aquino, M., \& Altavilla, G. (2019). Longitudinal case study of the role of libero in volleyball. Journal of Human Sport and Exercise, 14(4proc), S1112-S1121.

doi:https://doi.org/10.14198/ihse.2019.14.Proc4.75

Corresponding author. University of Salerno, Italy.

E-mail: fmarra16@gmail.com

Supplementary Issue: Spring Conferences of Sports Science. Costa Blanca Sports Science Events, 14-15 June 2019. Alicante, Spain.

JOURNAL OF HUMAN SPORT \& EXERCISE ISSN 1988-5202

(c) Faculty of Education. University of Alicante

doi:10.14198/jhse.2019.14.Proc4.75
\end{abstract}

S1112 | 2019| Proc4|VOLUME 14

C 2019 University of Alicante 


\section{INTRODUCTION}

The high-level agonistic female volleyball concerns that part of the volleyball which includes all categories of volleyball ranging from $A 1$ to $B 2$ series. In high-level competitive women's volleyball there is no monitoring system (D'Isanto et al, 2019), with the characteristics shown there, concerning training activities and the collection of qualitative (Tiziana et al, 2017) and quantitative information. (Di Tore et al, 2018). Do not forget that a monitoring process can be expected at any age (Parisi \& Raiola, 2014, Ferrara et al, 2019, Invernizzi et al, 2019), both on males and females (Altavilla et al, 2017). All types of analysis can be used to support this monitoring system, such as video analysis. (D'Elia et al, 2019, Raiola et al, 2013; lzzo et al, 2018). In essence, the evaluation of sports performance is fundamental at every level, in its theoretical aspects and its practical indications (Alminni et al, 2019ab). What is proposed in this article is a monitoring system for training activities in the context of high-level competitive women's volleyball. Monitoring means the application of a system which, based on the use of specific and appropriate criteria, aims to control the duration of a training or a whole competitions season in a structured manner and with recurrent step, for the purposes of:

- Highlight the trend, starting from elementary variables of the observed phenomenon;

- Record the deviations between what is taking place and what was expected;

- Inform the players of the monitoring system (recipients, beneficiaries, users, controllers) about the critical issues that arise from time to time to search for the most appropriate solutions.

By monitoring we therefore mean preparation of an information gathering system:

- Coded;

- Registered;

- Constantly updatable.

The monitoring system therefore constitutes the essential support to the evaluation process on the liberoathlete and on the workout methodology used (Raiola, 2014) by the coach or coaches. So thanks to data collected by this monitoring system, we can evaluate our training activities and the athletes in the role of libero (Altavilla, Raiola, 2018, D'Isanto et al, 2018, ). This type of system is being proposed because in the high-level competitive women's volleyball, in the role of the libero, scientific instruments and simple fruition about the objective monitoring of training actions and their effectiveness are lacking. Testing is used to measure the performance (Ferrara et al, 2018) and, therefore, to verify the resulting improvements to training activity (Forte et al, 2019). More and more frequently, coaches require checks even during the current sporting season to measure the state of the athletes' performance and possibly change their training plans in order to make them more effective. Increasingly testing has also a monitoring function and, therefore, is expected in the ordinary training activities without changing the annual planning. To do this, it is necessary to provide a type of functional tests for training.

The aim is to identify a monitoring system consisting of tests, which present a qualitative and quantitative numerical detection system. It intends to look for a monitoring system consisting of tests, which have a quali/quantitative numerical detection system. The tools, from which these numerical values of the tests derive, are compatible with the training activities as they don't influence the ordinary activities.

The aim is to constantly code, record and update training activities. Furthermore, there will be a quantification of the training activities of each individual athlete in the role of libero, so that the coach can decide game to 
game which of the libero-players is most effective at that time. In this way, each individual athlete will be stimulated to give the maximum of his possibilities every workout in order to be included in the initial roster.

\section{METHODS}

The method is experimental and longitudinal and it consists in detecting the initial and final data in a period of time of 8 months for the technical skill of Bagher, in different moments of the game, of a player in the role of libero in B1 series.

\section{Tests Description}

Bagher of free-ball (or easy-ball)

A first assistant throws the ball, with two hands from above the head, from 6 meters of the enemy camp. The player who is on the other side of the net will have to direct the ball, with the only fundamental of Bagher, to a second assistant positioned in place 3 by his own part of the field that, at the end of a series of 10 throws, will explain the result obtained by the player: in fact, only the balls that will reach precisely above the head of the assistant (positioned under the net and in place 3) will be counted.

This work will be repeated with a scan of 2 series of 10 throws from zone 1, zone 5 and zone 6 of the opponent's field towards zone 5 (where the libero is placed): the final result is given by the arithmetic mean between the two series for each position and thereafter compared with standardized performance parameters of the calibrated model for the B1 series.

The receiving of service

A first assistant, through the fundamental of the floating service feet-on-the-ground, directs the ball from nine meters of his part of the field toward the opponent's libero field. The player, who is located on the other side of the net will have to hit the ball, with the only fundamental of Bagher, pushing it to a second assistant positioned in place 3 from its own part of the field that, at the end of a series of 10 lines, will explain the result obtained by the player: in fact, only the balls that will reach precisely above the head of the assistant (under the net and in place 3) will be counted.

This work will be repeated with a scan of 2 series to 10 services from the zone 1, zone 5 and zone 6 of the opposing field directed towards the opposite zone 1, zone 5 and zone 6 (in which the libero will move to the end of the 2 series for zone): the final result will be obtained from the arithmetic mean between the two series for each position that will be compared subsequently with standardized performance parameters of the calibrated model for the B1 series.

The defence of spike

A first assistant is positioned on top of a plinth and, through the fundamental of the spike, he hits the ball to send it to the network beyond the net to place 5, where the libero-player is located ready to defend. A second assistant, positioned on the 3-meters-line, will evaluate how many balls defended by the player will fall in the delimited area:

- In length, from the net and the 3-meters-line;

- In width, by two strips of adhesive tape positioned midway between zone 4 and zone 3 and between place 2 and place 3. 
This work will be repeated with a scan of 2 series of 10 spikes from zone 4 and from zone 2 opponents exclusively towards area 5, because this is the part of the field where the libero is usually in defence: the final result will be given by the arithmetic mean between the two series for each position that will be compared subsequently with standardized performance parameters of the calibrated model for the B1 series.

\section{RESULTS}

\section{Bagher of free-ball (or easy-ball)}

Results obtained in the surveys in November, February and May are tabulated below:

Table 1. Bagher of free-ball (or easy-ball)

\begin{tabular}{ccccccccc}
\hline \multicolumn{10}{c}{ From the opponent's zone 1 to zone 5 } \\
\hline Date & $\#$ & + & - & -- & $\#$ & + & - & -- \\
$07 / 11 / 2018$ & 9 & 1 & $/$ & $/$ & 8 & 2 & $/$ & $/$ \\
$07 / 02 / 2019$ & 8 & 2 & $/$ & $/$ & 8 & 2 & $/$ & $/$ \\
$07 / 05 / 2019$ & 10 & $/$ & $/$ & $/$ & 9 & 1 & $/$ & $/$ \\
\hline
\end{tabular}

Table 2. Bagher of free-ball (or easy-ball)

\begin{tabular}{ccccccccc}
\hline \multicolumn{1}{c}{ From the opponent's zone $\mathbf{6}$ to zone 5} \\
\hline Date & $\#$ & + & - & -- & $\#$ & + & - \\
\hline $07 / 11 / 2018$ & 8 & 2 & $/$ & $/$ & 7 & 3 & $/$ & $/$ \\
$07 / 02 / 2019$ & 8 & 2 & $/$ & $/$ & 8 & 2 & $/$ & $/$ \\
$07 / 05 / 2019$ & 9 & 1 & $/$ & $/$ & 9 & 1 & $/$ & $/$ \\
\hline
\end{tabular}

Table 3. Bagher of free-ball (or easy-ball)

\section{From the opponent's zone 5 to zone 5}

\begin{tabular}{|c|c|c|c|c|c|c|c|c|}
\hline \multirow[t]{2}{*}{ Date } & \multicolumn{4}{|c|}{ 1st series } & \multicolumn{4}{|c|}{ 2nd series } \\
\hline & \# & + & - & -. & \# & + & - & - - \\
\hline $07 / 11 / 2018$ & 9 & 1 & 1 & 1 & 8 & 2 & 1 & 1 \\
\hline $07 / 02 / 2019$ & 8 & 2 & I & 1 & 8 & 2 & I & I \\
\hline $07 / 05 / 2019$ & 9 & 1 & 1 & 1 & 10 & 1 & 1 & 1 \\
\hline
\end{tabular}

Table 4. Comparison between series "free-ball" in the 3 areas (pre and post)

\section{Test paired samples}

\begin{tabular}{|c|c|c|c|c|c|c|c|c|}
\hline & \multicolumn{5}{|c|}{ Coupled Differences } & \multirow{3}{*}{$t$} & \multirow{3}{*}{ gl } & \multirow{3}{*}{$\begin{array}{l}\text { Sign. (Two- } \\
\text { tailed) }\end{array}$} \\
\hline & \multirow[t]{2}{*}{ Average } & \multirow{2}{*}{$\begin{array}{c}\text { Std } \\
\text { deviation }\end{array}$} & \multirow{2}{*}{$\begin{array}{c}\text { Average } \\
\text { standard error }\end{array}$} & \multicolumn{2}{|c|}{$\begin{array}{c}\text { Confidence interval of } 95 \% \\
\text { difference }\end{array}$} & & & \\
\hline & & & & lower & higher & & & \\
\hline $\begin{array}{l}\text { VAR1 - } \\
\text { VAR2 }\end{array}$ & -1.16667 & .75277 & 30732 & -1.95665 & -. 37668 & -3.796 & 5 & .013 \\
\hline
\end{tabular}

There is a significant difference $(0.013)$ between the pre- and post-series with $p>0.05$ 


\section{Receiving Bagher of service}

Results obtained in the surveys in November, February and May are tabulated below:

Table 5. Receiving Bagher of service

\begin{tabular}{|c|c|c|c|c|c|c|c|c|c|}
\hline \multicolumn{10}{|c|}{ Towards zone 6} \\
\hline \multirow[t]{2}{*}{ Date } & \multirow[t]{2}{*}{ From opponent's zone } & \multicolumn{4}{|c|}{ 1st series } & \multicolumn{4}{|c|}{ 2nd series } \\
\hline & & \# & + & - & -- & \# & + & - & -- \\
\hline \multirow{3}{*}{$07 / 11 / 2018$} & 1 & 4 & 6 & I & I & 5 & 5 & I & l \\
\hline & 6 & 6 & 4 & 1 & 1 & 4 & 5 & 1 & 1 \\
\hline & 5 & 5 & 3 & 1 & 1 & 5 & 2 & 2 & 1 \\
\hline \multirow[t]{3}{*}{ 07/02/2019 } & 1 & 4 & 3 & 2 & 1 & 3 & 5 & 2 & l \\
\hline & 6 & 4 & 3 & 1 & 2 & 2 & 3 & 2 & 3 \\
\hline & 5 & 5 & 2 & 1 & 2 & 6 & 2 & 1 & 1 \\
\hline \multirow[t]{3}{*}{ 07/05/2019 } & 1 & 7 & 2 & 1 & l & 6 & 4 & 1 & 1 \\
\hline & 6 & 5 & 2 & 1 & 1 & 6 & 2 & 2 & l \\
\hline & 5 & 6 & 3 & 1 & 1 & 1 & 7 & 1 & 2 \\
\hline \multicolumn{10}{|c|}{ Towards zone 1} \\
\hline \multirow[t]{2}{*}{ Date } & From opponent's zone & \multicolumn{4}{|c|}{ 1st series } & \multicolumn{4}{|c|}{ 2nd series } \\
\hline & & \# & + & - & - & \# & + & - & - \\
\hline \multirow[t]{3}{*}{ 07/11/2018 } & 1 & 8 & 1 & 1 & 1 & 3 & 5 & 2 & 1 \\
\hline & 6 & 4 & 2 & 3 & 1 & 5 & 3 & 2 & 1 \\
\hline & 5 & 4 & 4 & 1 & 2 & 7 & 1 & 2 & 1 \\
\hline \multirow[t]{3}{*}{ 07/02/2019 } & 1 & 2 & 5 & 1 & 2 & 6 & 3 & 1 & 1 \\
\hline & 6 & 5 & 2 & 1 & 2 & 5 & 2 & 2 & 1 \\
\hline & 5 & 2 & 3 & 3 & 2 & 4 & 1 & 3 & 2 \\
\hline \multirow[t]{3}{*}{ 07/05/2019 } & 1 & 8 & 2 & 1 & 1 & 7 & 3 & 1 & 1 \\
\hline & 6 & 6 & 2 & 1 & 1 & 7 & 2 & 1 & 1 \\
\hline & 5 & 7 & 1 & 1 & 1 & 7 & 2 & 1 & 1 \\
\hline
\end{tabular}

Table 6. Comparison between the series "reception of the service" in the two zones 1 and 6 (pre and post) Test paired samples

\begin{tabular}{|c|c|c|c|c|c|c|c|c|}
\hline & \multicolumn{5}{|c|}{ Coupled Differences } & \multirow{3}{*}{$\mathrm{t}$} & \multirow{3}{*}{$\mathrm{gl}$} & \multirow{3}{*}{$\begin{array}{l}\text { Sign. } \\
\text { (Two- } \\
\text { tailed) }\end{array}$} \\
\hline & \multirow[t]{2}{*}{ Average } & \multirow{2}{*}{$\begin{array}{c}\text { Std } \\
\text { deviation }\end{array}$} & \multirow{2}{*}{$\begin{array}{c}\text { Average } \\
\text { standard } \\
\text { error }\end{array}$} & \multicolumn{2}{|c|}{$\begin{array}{l}\text { Confidence interval of } \\
95 \% \text { difference } \\
\end{array}$} & & & \\
\hline & & & & lower & higher & & & \\
\hline $\begin{array}{l}\text { VAR1- } \\
\text { VAR2 }\end{array}$ & -1.08333 & 2.15146 & 62107 & -2.45031 & .28364 & -1.744 & 11 & 109 \\
\hline
\end{tabular}

There isn't a significant difference $(0.109)$ between the pre- and post-series with $p>0.05$

Defence Bagher of spike

Results obtained in the surveys in November, February and May are tabulated below: 
Table 7. Defence Bagher of spike

From the opponent's zone 4 towards zone 5

\begin{tabular}{ccccccccc}
\hline Date & \multicolumn{3}{c}{ 1st series } & \multicolumn{5}{c}{ 2nd series } \\
\hline & $\#$ & + & - & -- & $\#$ & + & - & -- \\
$07 / 11 / 2018$ & 9 & 1 & $/$ & $/$ & 9 & 1 & $/$ & $/$ \\
$07 / 02 / 2019$ & 8 & 1 & 1 & $/$ & 7 & 2 & $/$ & 1 \\
$07 / 05 / 2019$ & 10 & $/$ & $/$ & $/$ & 9 & 1 & $/$ & $/$ \\
\hline
\end{tabular}

Table 8. Defence Bagher of spike

\begin{tabular}{ccccccccc}
\hline \multicolumn{10}{c}{ From the opponent's zone 2 towards zone 5 } \\
\hline Date & $\#$ & + & - & - & $\#$ & + & - \\
\hline $07 / 11 / 2018$ & 7 & 2 & 1 & $/$ & 7 & 3 & $/$ & $/$ \\
$07 / 02 / 2019$ & 6 & 1 & 2 & 1 & 6 & 3 & $/$ & 1 \\
$07 / 05 / 2019$ & 8 & 2 & $/$ & $/$ & 8 & 2 & $/$ & $/$ \\
\hline
\end{tabular}

Table 9. Comparison between the "defence of the spike" series in the 2 areas (pre and post) Test paired samples

\begin{tabular}{|c|c|c|c|c|c|c|c|c|}
\hline & \multicolumn{5}{|c|}{ Coupled Differences } & \multirow{3}{*}{$t$} & \multirow{3}{*}{ gl } & \multirow{3}{*}{$\begin{array}{l}\text { Sign. } \\
\text { (Two- } \\
\text { tailed) }\end{array}$} \\
\hline & \multirow[t]{2}{*}{ Average } & \multirow{2}{*}{$\begin{array}{c}\text { Std } \\
\text { deviation }\end{array}$} & \multirow{2}{*}{$\begin{array}{c}\text { Average } \\
\text { standard error }\end{array}$} & \multicolumn{2}{|c|}{\begin{tabular}{|c|}
$\begin{array}{c}\text { Confidence interval of } \\
95 \% \text { difference }\end{array}$ \\
\end{tabular}} & & & \\
\hline & & & & lower & higher & & & \\
\hline $\begin{array}{l}\text { VAR1- } \\
\text { VAR2 }\end{array}$ & -.75000 & 46291 & .16366 & $\mid-1.13700$ & -.36300 & -4.583 & 7 & .003 \\
\hline
\end{tabular}

There is a significant difference $(0.003)$ between the pre- and post-series with $p>0.05$.

The tests results were also graphically represented by the histograms so as to be able to enclose in a small space the representation of a test season:

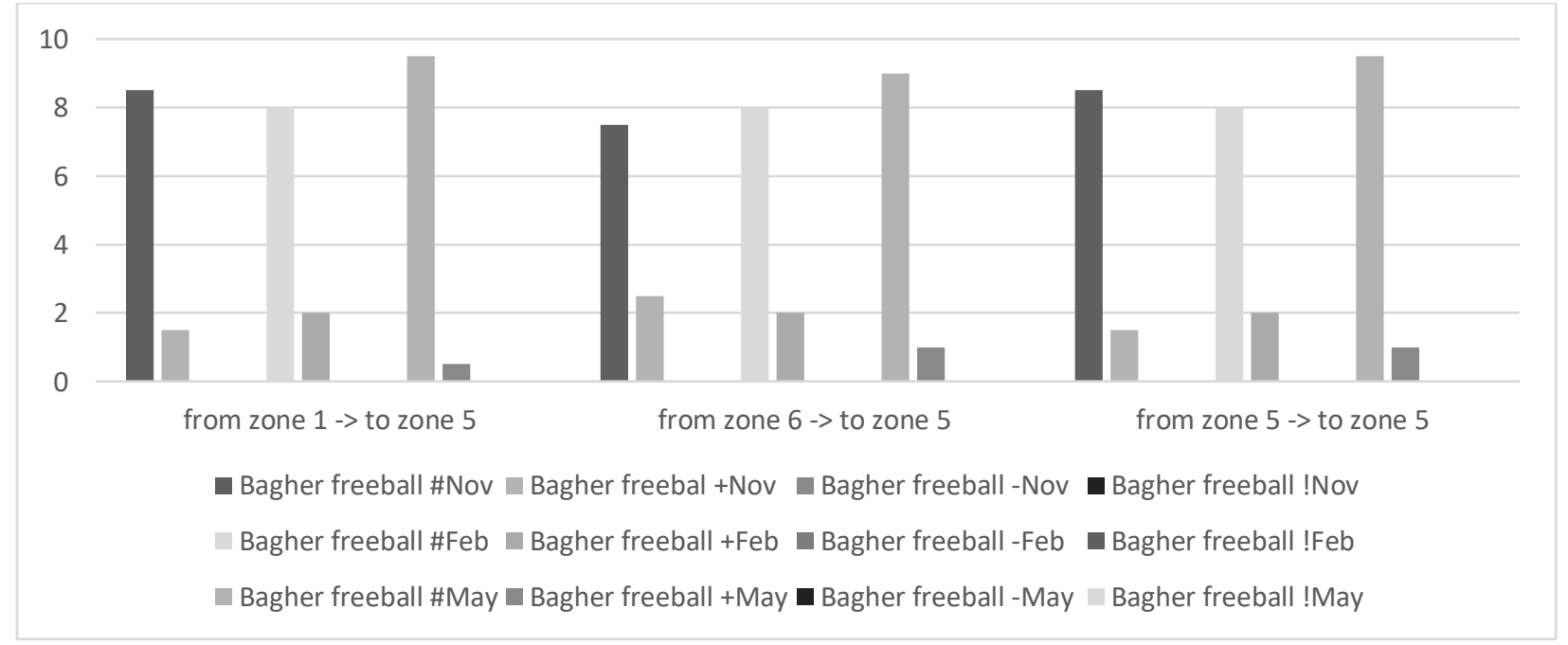

Figure 1. Results of Bagher of free-ball. 


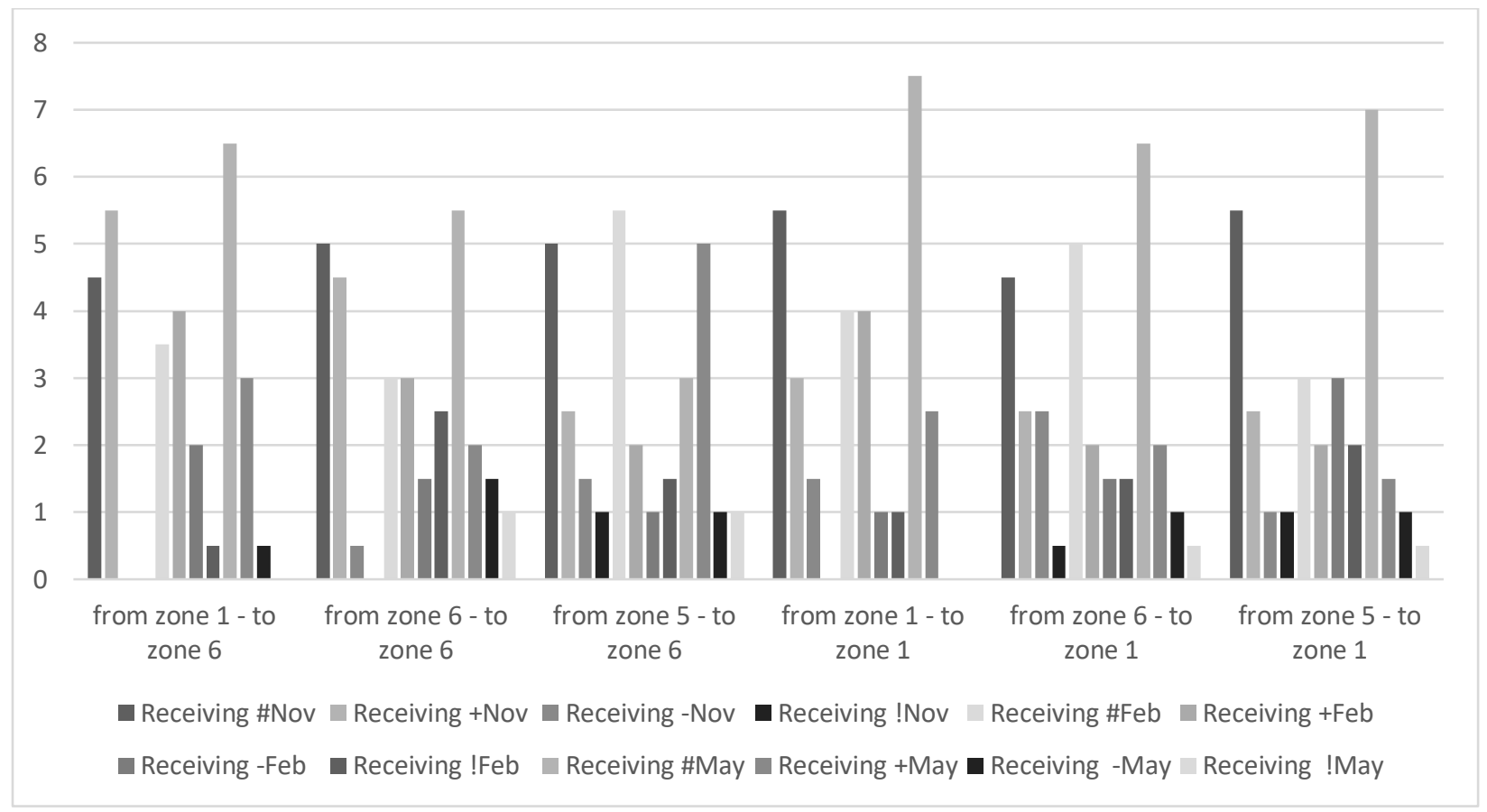

Figure 2. Results of receiving Bagher of service.

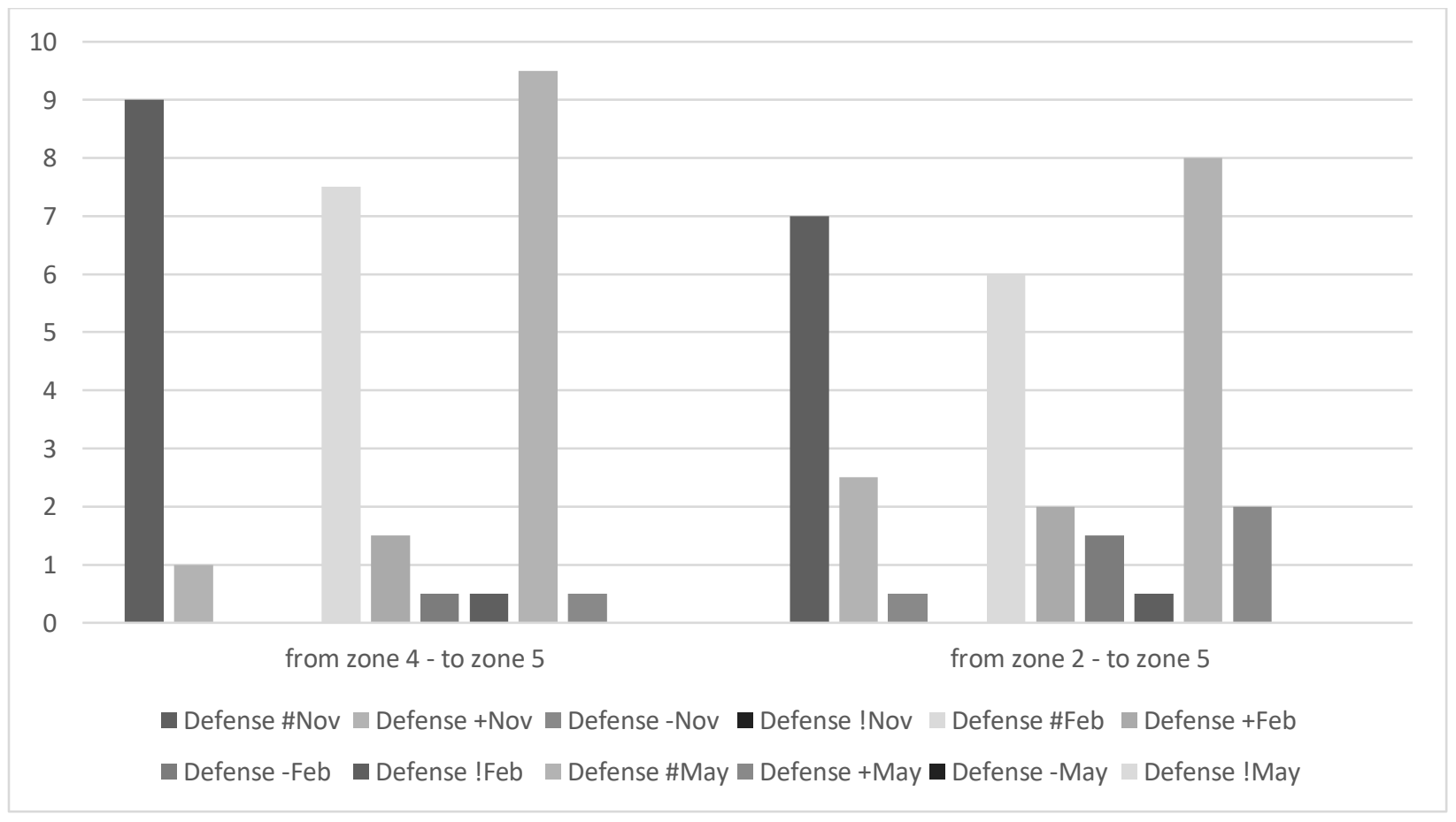

Figure 3. Results of defence Bagher of spike. 


\section{DISCUSSION}

There have been significant improvements in the Bagher of free-ball (Tab. 4) with $p=0.013$ and in the defence Bagher spike (Tab. 9) with $p=0.003$; while on the receiving Bagher of service (Tab. 6) there wasn't a significant improvement with $p=0.109$.

The use of T-test of Student for paired data (pre and post) confirms that there have been these significant improvements compared to the percentages given.

With these simple tables we managed to build a system for monitoring the progress of training activities in an entire season. The surveys took place every three months. Each of detections cycle we went to check which part of the fundamental of the Bagher was increased and which not. Libero-players appeared very excited about the new monitoring system. These tests have supported the technical and tactical evaluation and intrinsic motivation of the girls to be examined.

\section{CONCLUSION}

Tests have once against shown that constant training is the only winning key in sport in general and above all in volleyball, especially for the libero-player: in fact, this role requires a greater technique than the others, almost perfect... so it must always be solicited during training, even individually!

In particular, from the results it turns out that the training activities are constantly monitored and, therefore, the purpose can be considered achieved because the coach has occurred over time the level of athlete's performance also noting a final performance improvement, confirmed by data collected during the competitions too.

In conclusion, the study was useful for the purpose but it is necessary to improve the evaluation tools and adapt them to the training plans. An improvement of this system is envisaged with the addition of tests to monitor the fundamental of defence Bagher also on the spike from opponent's areas 3 and 6 .

\section{REFERENCES}

Alminni, C., Altavilla, G., Cassese, F.P., Ceciliani, A., D'isanto, T. (2019b) Physical and motor tests to estimate the improvement of the float serve, Journal of Human Sport and Exercise, 14 (Proc2), pp. S245-S250. https://doi.org/10.14198/hse.2019.14.proc2.13

Altavilla, G., Gaetano, R. (2018). Physiological effects of warm-up and problems related to team sports, Sport Science, 11, 83-88.

Altavilla, G., Di Tore, P.A., Riela, L., D'Isanto, T. (2017) Anthropometric, physiological and performance aspects that differentiate male athletes from females and practical consequences, Journal of Physical Education and Sport, 17(226):2183-2187.

D'Isanto, T., D'Elia, F., Raiola, G., Altavilla, G. (2019). Assessment of sport performance: Theoretical aspects and practical indications, Sport Mont, 17 (1):79-82.

D'Isanto, T., Di Tore, P.A., Altavilla, G. (2018). Correlation of the anthropometric characteristics and the ability to jump in volleyball, Journal of Human Sport and Exercise, 13, S393-\$400. https://doi.org/10.14198//hse.2018.13.proc2.23 
D'Isanto, T., Altavilla, G., Raiola, G. (2017). Teaching method in volleyball service: Intensive and extensive tools in cognitive and ecological approach. Journal of Physical Education and Sport, 17(S5): 2222-2227.

Tiziana, D., Antonetta, M., Gaetano, A. (2017). Health and physical activity, Sport Science, 10 (1):100105.

Di Tore, A.P., Raiola, G., D'Isanto, T. (2018). Situation awareness in sports science: Beyond the cognitive paradigm, Sport Science, 11 (1):44-48.

Ferrara, F., Di Tore, P.A., Gaetano, R. (2018). Preliminary work on the testing of power glove applied to volleyball, Journal of Physical Education and Sport, 18(294):1986-1990.

Ferrara, F., Izzo, R., Ceciliani, A., Di Tore, A.P. (2019)Pilot study on the testing of Power Glove applied to volleyball, Journal of Human Sport and Exercise, 14 (Proc2), pp. S233-S238. https://doi.org/10.14198/ihse.2019.14.proc2.11

Invernizzi, P.L., Crotti, M., Bosio, A., Cavaggioni, L., Alberti, G., Scurati, R. (2019)Multi-teaching styles approach and active reflection: Effectiveness in improving fitness level, motor competence, enjoyment, amount of physical activity, and effects on the perception of physical education lessons in primary school children, Sustainability (Switzerland), 11 (2). https://doi.org/10.3390/su11020405

Forte, D., Ceciliani, A., Izzo, R., Altavilla, G. (2019). Transition period: Pilot study on performance reduction of ability to jump in volleyball, Journal of Human Sport and Exercise, 14 (Proc2): S221S227. https://doi.org/10.14198/ihse.2019.14.proc2.09

Izzo, R., Sopranzetti, S., Hosseini Varde'I, C., Molitierno, G. (2018). Video tracking for the detection of external load to establish proper parameters in elite soccer players during high intensity training, Journal of Physical Education and Sport, 18(178):1199-1202.

Parisi, F., Raiola, G. (2014). Video analysis in youth volleyball team, Journal of Human Sport and Exercise, 9, S584-S587. https://doi.org/10.14198//hse.2014.9.proc1.50

Raiola, G. (2014). Teaching method in young female team of volleyball, Journal of Physical Education and Sport, 14 (1): 74-78.

Raiola, G., Parisi, F., Giugno, Y., Di Tore, P.A. (2013). Video analysis applied to volleyball didactics to improve sport skills, Journal of Human Sport and Exercise, 8 (2 Suppl):307-313. https://doi.org/10.4100/ihse.2012.8.proc2.33

Izzo, R., Sopranzetti, S., Hosseini Varde'l, C., Molitierno, G. (2018). Video tracking for the detection of external load to establish proper parameters in elite soccer players during high intensity training, Journal of Physical Education and Sport, 18(178):1199-1202.

Parisi, F., Raiola, G. (2014). Video analysis in youth volleyball team, Journal of Human Sport and Exercise, 9, S584-S587. https://doi.org/10.14198//hse.2014.9.proc1.50

Raiola, G., Parisi, F., Giugno, Y., Di Tore, P.A. (2013). Video analysis applied to volleyball didactics to improve sport skills, Journal of Human Sport and Exercise, 8 (2 Suppl): 307-313. https://doi.org/10.4100/jhse.2012.8.proc2.33

Raiola, G. (2014). Teaching method in young female team of volleyball, Journal of Physical Education and Sport, 14 (1): 74-78.

Raiola, G., Di Tore, P.A. (2012a) Statistical study on bodily communication skills in volleyball to improve teaching methods, Journal of Human Sport and Exercise, 7 (2), pp. 468-488. https://doi.org/10.4100/ihse.2012.72.12

Raiola, G., Di Tore, P.A. (2012b) Bodily communication skills and its incidence on female volleyball championship to enhance didactics, Journal of Human Sport and Exercise, 7 (2), pp. 365-375. https://doi.org/10.4100/jhse.2012.72.03

Raiola, G., D'isanto, T. (2016). Assessment of periodization training in soccer, Journal of Human Sport and Exercise, 11 (Proc1): S267-S278. https://doi.org/10.14198/ihse.2016.11.proc1.19 


\section{(c) $($ i) () $९$}

This work is licensed under a Attribution-NonCommercial-NoDerivatives 4.0 International (CC BY-NC-ND 4.0). 